\title{
The effects of milking frequency in early lactation on milk yield, mammary cell turnover, and secretory activity in grazing dairy cows
}

\author{
R. Murney, ${ }^{*} \dagger^{1}$ K. Stelwagen, $\ddagger$ T. T. Wheeler, ${ }^{*}$ J. K. Margerison, $\dagger$ and K. Singh ${ }^{*}$ \\ ${ }^{*}$ AgResearch Ltd., Ruakura Research Centre, P.B. 3123, Hamilton 3240, New Zealand \\ †Institute of Agriculture and Environment, College of Sciences, Massey University, P.B. 11222, Palmerston North 4442, New Zealand \\ $\ddagger$ SciLactis Ltd., Waikato Innovation Park, Hamilton 3240, New Zealand
}

\section{ABSTRACT}

In dairy cows, short-term changes of milking frequency in early lactation have been shown to produce an immediate and a long-term effect on milk yield in stall-fed cows. The effect is controlled locally within mammary glands and could be a function of either secretory mammary epithelial cell number or activity. To resolve this and determine its applicability in other feed management systems, a unilateral milking frequency experiment was conducted with udder halves of 17 multiparous, pasture-fed dairy cows milked either 4 times $(4 \times)$ or once a day $(1 \times)$ for $14 \mathrm{~d}$ from $5 \pm 2 \mathrm{~d}$ in milk. Mean half-udder milk yield during the treatment period was higher from the $4 \times$ compared with $1 \times$ udder halves and continued to be higher until $200 \mathrm{~d}$ in milk once returned to twice a day milking. Mammary biopsies were obtained on d 14 of treatment from both udder halves of 10 cows. Proliferation of mammary cells was higher in $4 \times$ udder halves compared with $1 \times$, whereas no difference in apoptosis levels was detected. Abundance of $\alpha_{\mathrm{S} 1}$-casein, $\beta$-casein, $\alpha$-lactalbumin, and $\beta$-lactoglobulin mRNA was higher in tissue samples from $4 \times$ udder halves compared with $1 \times$, whereas lactoferrin mRNA abundance was lower in $4 \times$ udder halves. In summary, change in milking frequency during early lactation affects proliferation of mammary cells as well as expression of the major milk protein genes, which both contribute to the observed changes in milk yield during and after unilateral milking frequency treatment.

Key words: milking frequency, grazing dairy cow, early lactation, milk yield, cell proliferation

\section{INTRODUCTION}

Dairy cows are commonly milked twice a day $(2 \times)$. Increasing milking frequency $(\mathbf{M F})$ to $3(\mathbf{3} \times)$ or 4

\footnotetext{
Received August 14, 2014.

Accepted October 8, 2014.

${ }^{1}$ Corresponding author: regan.murney@agresearch.co.nz
}

$(4 \times)$ times a day has a dramatic effect on milk yield (MY; Amos et al., 1985; Hale et al., 2003). This response is immediate (Hillerton et al., 1990) and has been observed at most stages of lactation (reviewed in Erdman and Varner, 1995), provided sufficient nutrition has been supplied to the animals to accommodate the increased production (Phillips et al., 1980). In addition, short-term increased MF can have a long-term carry-over effect on MY even after the cows have been returned to a normal milking regimen (Bar-Peled et al., 1995; Hale et al., 2003; Wall and McFadden, 2007). This effect is most notable in early lactation, where 2 to $3 \mathrm{wk}$ of increased MF can positively influence MY for the remainder of lactation (Hale et al., 2003; Wall and McFadden, 2007), but has also been demonstrated in midlactation following 8 wk of $3 \times$ versus once daily $(\mathbf{1} \times)$ milking (Bernier-Dodier et al., 2010). In most cases, experiments examining increased MF have been conducted in confinement settings, where cows are housed indoors and fed a controlled diet. A few studies have attempted to measure the effects of increased MF during early lactation in grazing dairy cows (McNamara et al., 2008; Phyn et al., 2011). However, in these studies, a treatment of $3 \times$ milking for 3 wk yielded a modest increase in MY, but with no long-term effect post-treatment (Phyn et al., 2011) or no effect on MY at all (McNamara et al., 2008).

Similarly, decreasing MF below $2 \times$ to $1 \times$ has a negative effect on MY (Carruthers et al., 1993; Rémond et al., 1999; Phyn et al., 2011). As well as having an effect on MY during the treatment, if applied in early lactation, a temporary reduction in MF can also illicit a long-term negative carryover effect on MY (Rémond et al., 1999) or the treatment negatively affects levels of milk solids rather than MY (Phyn et al., 2011).

Studies using unilateral MF (UMF) models, where udder halves are milked independently at differing MF, have demonstrated that the effects on MY are predominantly controlled locally within the treated mammary gland (Hillerton et al., 1990; Stelwagen and Knight, 1997; Wall and McFadden, 2007). This has been observed for both the immediate effects of increased 
(Hillerton et al., 1990; Wall and McFadden, 2007) and decreased (Stelwagen and Knight, 1997) MF, as well as the carry-over effect associated with temporary increased MF in early lactation (Wall and McFadden, 2007) and midlactation (Bernier-Dodier et al., 2010). Furthermore, the MY response to UMF is equivalent to what has been seen in whole animal MF experiments, which suggest the underlying mechanisms are the same (Wall and McFadden, 2007). The advantage of utilizing a UMF model is that it is within animal and therefore the effects of genetics, nutrition, and environmental factors are largely negated.

The mechanisms underlying the MY response to MF are not well understood, but are most likely a function of secretory mammary epithelial cell (MEC) number or activity. To date, studies reporting the effects of MF during early lactation on cell turnover (a factor of the rate of proliferation and apoptosis) have been unclear. Hale et al. (2003), comparing $4 \times$ to $2 \times \mathrm{MF}$, were unable to detect any significant difference in proliferation. However, a significant increase in apoptosis in samples from $4 \times$-milked glands was observed after $3 \mathrm{~d}$ of treatment, but this difference was not detected at a later time point (Hale et al., 2003). Conversely, Nørgaard et al. (2005) saw no difference in proliferation or apoptosis following a 7 -d $4 \times$ MF compared with $2 \times$. Grala et al. (2011) reported an increase in apoptosis-related genes in mammary samples from cows milked $1 \times$ for 3 and 6 wk compared with $2 \times$. However, no proliferation markers were measured to ascertain the effects of $1 \times$ milking on combined cell turnover. Bernier-Dodier et al. (2010) detected an increase in both proliferation and apoptosis when $1 \times$ was compared with $3 \times$ by UMF in midlactation dairy cows, suggesting the decreased MF initiated tissue remodeling. In the current study, a UMF model was used to compare udder halves of grazing dairy cows milked $4 \times$ versus $1 \times$ for $14 \mathrm{~d}$ to investigate how shortterm MF changes in early lactation can affect MY both during and after treatment, along with cell turnover and cellular activity in the mammary glands.

\section{MATERIALS AND METHODS}

\section{Animals and Treatments}

All animal manipulations were conducted in compliance with the rules and guidelines of the Ruakura Animal Ethics Committee. Seventeen multiparous Holstein-Friesian and Holstein-Friesen $\times$ Jersey cows were freely grazed on pasture and given access to $2 \mathrm{~kg} / \mathrm{d}$ of commercial supplement (Topcow dairy, Ingham Feeds \& Nutrition, Te Aroha, New Zealand; $12.9 \mathrm{MJ} / \mathrm{kg}$ of ME, $12 \% \mathrm{CP}$ based on $\mathrm{DM})$. Initially the cows were milked $2 \times$ and then, from $5 \pm 2$ to $19 \pm 2$ DIM, randomly as- signed udder halves of all cows were unilaterally milked ( $1 \times$ in 1 udder half at $1100 \mathrm{~h}$, and $4 \times$ in the other half at $0500,1100,1700$, and $2300 \mathrm{~h}$ ). On the final day of treatment, 3 to $5 \mathrm{~h}$ following the 1100-h milking, mammary tissue was obtained by biopsy from both rear quarters of 10 cows, as previously described by Farr et al. (1996). A portion of the mammary tissue was fixed overnight in $4 \%$ paraformaldehyde and processed into wax as described previously (Singh et al., 2005). The remainder was snap-frozen in liquid nitrogen for subsequent molecular analysis. The cows were then returned to $2 \times$ milking for the remainder of lactation.

\section{Half-Udder MY and Composition Data}

Half-udder MY data were measured using a custombuilt 2-cup milk claw installed on a commercial rotary milking parlor (Tokanui Research Farm, Waikato, New Zealand), with the yields calculated using an in-line iNTELSCAN Plus milk meter (Milfos International Ltd., Hamilton, New Zealand). Milk yield data were collected daily during the treatment period and monthly following treatment until $200 \pm 2$ DIM. During the post-treatment period, milk samples were collected and analyzed by infrared spectrometry for fat, protein and lactose, and by flow cytometry for SCC (Fossomatic equipment, LIC Herd Testing Station, Hamilton, New Zealand).

\section{Cell Proliferation}

Immunohistochemical localization of the Ki-67 cell proliferation antigen was optimized from the method previously described by Capuco et al. (2001). Slides were deparaffinized, rehydrated, and antigen retrieval was carried out as described previously (McMahon et al., 2004). Slides were then quenched with Dual Endogenous Block (Dako Cytomation California Inc., Carpentaria, CA), washed 3 times in Tris-buffered saline solution (0.05 $M$ Tris-HCl, $0.15 M \mathrm{NaCl}, \mathrm{pH} 7.6)$ containing $0.05 \%$ Tween 20 (TBST), blocked with Biotin Blocking System (Dako), washed in TBST, and then blocked in 2.5\% BSA (Life Technologies, Grand Island, NY) in TBST. Slides were then incubated either with 1:100 anti-Ki-67 rabbit monoclonal antibody (Abcam, Cambridge, UK) diluted in antibody diluent (Stressmarq, Victoria, Canada) or diluent alone as a negative control overnight at $4^{\circ} \mathrm{C}$. Slides were washed 3 times in TBST and incubated with a 1:50 biotinylated antirabbit secondary antibody (Biogenex, Fremont, CA) in antibody diluent (Stressmarq) for 30 min. After 3 washes in TBST the slides were then incubated with 1:50 horseradish peroxidase (HRP)-conjugated strepavidin (Biogenex) diluted in antibody diluent (Stressmarq) for 
Table 1. Primer sequences for bovine Bcl-2-associated X protein $(B A X)$, B-cell lymphoma-extra-large $(B C L-X L), \alpha_{S^{-}} \mathrm{CN}, \beta-\mathrm{CN}, \alpha-\mathrm{LA}, \beta$-LG, lactoferrin $(\mathrm{LF})$, ubiquitin $\mathrm{B}(U B B)$, and $\beta-2$ microglobulin $(B 2 M)$

\begin{tabular}{|c|c|c|c|c|}
\hline Target & GeneBank no. & Forward & Reverse & Reference \\
\hline$B C L-X L$ & NM_001077486 & gcgtagacaaggagatgcag & gttccacaaaagtgtcccag & - \\
\hline$\alpha-\mathrm{LA}$ & NM_174378 & tgggtctgtaccacgtttca & gctttatgggccaaccagta & - \\
\hline$\beta-\mathrm{LG}$ & NM_173929 & cattgtcacccagaccatga & cactcaccgttctcccattt & - \\
\hline LF & NM_180998 & ggcctttgccttggaatgtatc & atttagccacagctccctggag & Singh et al., 2008 \\
\hline
\end{tabular}

30 min. Slides were then washed 3 times in TBST and to visualize the Ki-67 positive nuclei the slides were incubated with 3,3'-diaminobenzidine substrate (Roche, Basel, Switzerland) for $2 \mathrm{~min}$. Slides were rinsed in deionized water and counterstained with hematoxylin, dehydrated, washed with xylene and then mounted with DePeX mounting medium (VWR International Ltd., Poole, UK). The proportion of Ki-67-positive cells was determined by comparing the number of Ki-67-positive cells to the total number of cells per field at $100 \times$ magnification using a binocular microscope (Olympus Optical Co. Ltd., London, UK). Images were captured of 4 fields per cow per treatment using a Prog14 digital camera (Jenoptik GmbH, Jena, Germany). Cells were counted manually using Image-Pro Plus Version 7.0 (Media Cybernetics Inc., Bethesda, MD) software and a total of 6,000 or more cells were counted across the 4 fields for each section.

\section{RNA Isolation and Reverse Transcription}

Total RNA was isolated from $100 \mathrm{mg}$ of mammary tissue using Trizol reagent (Life Technologies) accord- ing to the manufacturer's instructions and quantified using a Nanodrop 1000 (Nanodrop, Wilmington, DE). The RNA integrity was measured on an Agilent 2100 Bioanalyser (Agilent, Santa Clara, CA) with an RNA integrity number (RIN) $>5$ considered sufficient for real time reverse transcription PCR analysis. Total RNA (1 $\mu \mathrm{g}$ ) was purified using columns (Qiagen, Valencia, CA) and used as a template to produce cDNA using the SuperScript III reverse transcription kit (Life Technologies) according to the manufacturer's instructions. The amount of cDNA equivalent to $5 \mathrm{ng}$ of starting total RNA was used as template for each real time PCR reaction. Primers for pro-apoptotic Bcl-2-associated X protein $(B A X)$, antiapoptotic B-cell lymphoma-extralarge $(B C L-X L), \alpha_{S_{1}}-\mathrm{CN}, \alpha-\mathrm{LA}$, and $\beta$-LG mRNA were designed using Primer3 (Rozen and Skaletsky, 2000) and are listed in Table 1. Primers for $\beta$-CN, lactoferrin (LF), and ubiquitin B were from Singh et al. (2008) and primers for $\beta-2$ microglobulin were from Wall and McFadden (2010). Abundance of mRNA of milk protein genes $\alpha_{\mathrm{S} 1}-\mathrm{CN}, \beta-\mathrm{CN}, \alpha-\mathrm{LA}, \beta-\mathrm{LG}$, and $\mathrm{LF}$ was normalized to the geometric mean of the mRNA abundance of 2 housekeeper genes (ubiquitin B and

Table 2. Half-udder milk yield (MY) and milk composition data for pretreatment, treatment, and posttreatment periods ${ }^{1}$

\begin{tabular}{lccccc}
\hline Item & $4 \times$ & $1 \times$ & $4 \times-1 \times$ & SED & $P$-value \\
\hline $\begin{array}{l}\text { Pretreatment (3-4 DIM) } \\
\text { MY (kg/d) }\end{array}$ & 8.5 & 8.4 & 0.1 & 0.3 & NS \\
Treatment (5-19 DIM) & & & & & \\
MY (kg/d) & 13.8 & 7.7 & 6.1 & 0.2 & $<0.001$ \\
Posttreatment (55-200 DIM) & 10.0 & 8.9 & 1.1 & 0.2 & $<0.001$ \\
MY (kg/d) & 5.20 & 5.00 & 0.2 & 0.08 & $<0.05$ \\
Fat (\%) & 3.44 & 3.47 & -0.03 & 0.02 & NS \\
Protein (\%) & 4.93 & 4.90 & 0.03 & 0.02 & NS \\
Lactose (\%) & 500 & 430 & 70 & 10 & $<0.001$ \\
Fat (g/d) & 330 & 300 & 30 & 10 & $<0.001$ \\
Protein (g/d) & 480 & 430 & 50 & 10 & $<0.001$ \\
Lactose (g/d) & 1.81 & 1.77 & 0.04 & 0.06 & NS \\
SCC (Log 10 cells/mL) & & & & & \\
\hline
\end{tabular}

${ }^{1}$ Cows were milked twice daily during pretreatment (3-4 DIM) and then udder halves were milked either 4 times a day $(4 \times)$ or once a day $(1 \times)$ during treatment (5-19 DIM). Following the treatment period, cows were returned to twice daily milking for the remainder of lactation (post-treatment, 55-200 DIM). Half-udder MY were collected for all 3 periods, whereas milk composition and SCC data were collected during the posttreatment period only. Data $(4 \times$ and $1 \times)$ are expressed as treatment means and the difference between the means $(4 \times-1 \times)$ and standard error of the difference (SED) are indicated. 
$\beta 2$-microglobulin). To measure relative apoptosis levels, the ratio of $B A X$ and $B C L-X L$ mRNA abundance was compared between treatments. The PCR products were verified by sequencing (Waikato DNA Sequencing Facility, Hamilton, New Zealand).

\section{Statistical Analysis}

Differences between half-udder MY (means of 2 subsequent days), milk composition, and $\log _{10}$-transformed SCC were analyzed by ANOVA (Minitab 16.2.2, 2010, State College, PA) by treatment, DIM, and their interaction, with cow as a random effect. Differences between the proportion of Ki-67-positive cells, $B A X$-to- $B C L-X L$ ratio, and $\log _{10}$-transformed normalized mRNA abundance were analyzed by ANOVA (Minitab 16.2.2) by treatment with cow as a random effect. The MY, proportion of Ki-67-positive cells, and $B A X$-to- $B C L-X L$ ratios were expressed as means \pm SEM. The differences in MY, milk composition, and $\log _{10}$-transformed SCC were shown as means with standard error of the difference. The differences in mRNA abundance were backtransformed and expressed as the $4 \times$ mean fold change \pm standard error of the difference. Differences between means were considered significant at $P<0.05$.

\section{RESULTS}

Pretreatment MY (3-4 DIM) was similar for $4 \times$ and $1 \times$ udder halves (Table 2). By d 2 of treatment (i.e., 6 DIM), the MY of $4 \times$-milked udder halves was higher compared with $1 \times$ and remained elevated during the UMF treatment period. This resulted in an $80 \%$ higher MY from the $4 \times$ udder halves (Figure 1A, Table 2). Once both udder halves had been returned to $2 \times$, the $4 \times$ udder halves continued to produce more milk than the $1 \times$ udder halves (Figure 1B, Table 2). The increase in $4 \times$ MY was detectable until 200 DIM and corresponded to an overall increase in MY of $12 \%$ across the post-treatment period (55-200 DIM). Percentage of fat was higher in milk samples collected from $4 \times$ udder halves compared with $1 \times$, whereas lactose and protein percentage were not significantly different between $4 \times$ and $1 \times$ (Table 2 ). Total daily yields of fat, protein, and lactose were 16, 10, and $12 \%$ higher, respectively, from $4 \times$ udder halves compared with $1 \times$ (Table 2 ). No difference in SCC was detected between the $4 \times$ and $1 \times$ udder halves (Table 2).

The relative number of proliferating cells within the $4 \times$ - and $1 \times$-milked mammary tissue samples was measured by Ki-67 localization. The number of Ki67-positive cells in tissue samples from $4 \times$ udder halves was $32 \%$ higher $(P<0.05)$ than in $1 \times$ (Figure $2 \mathrm{~A}$ ). Representative images of the Ki-67 assay are shown for
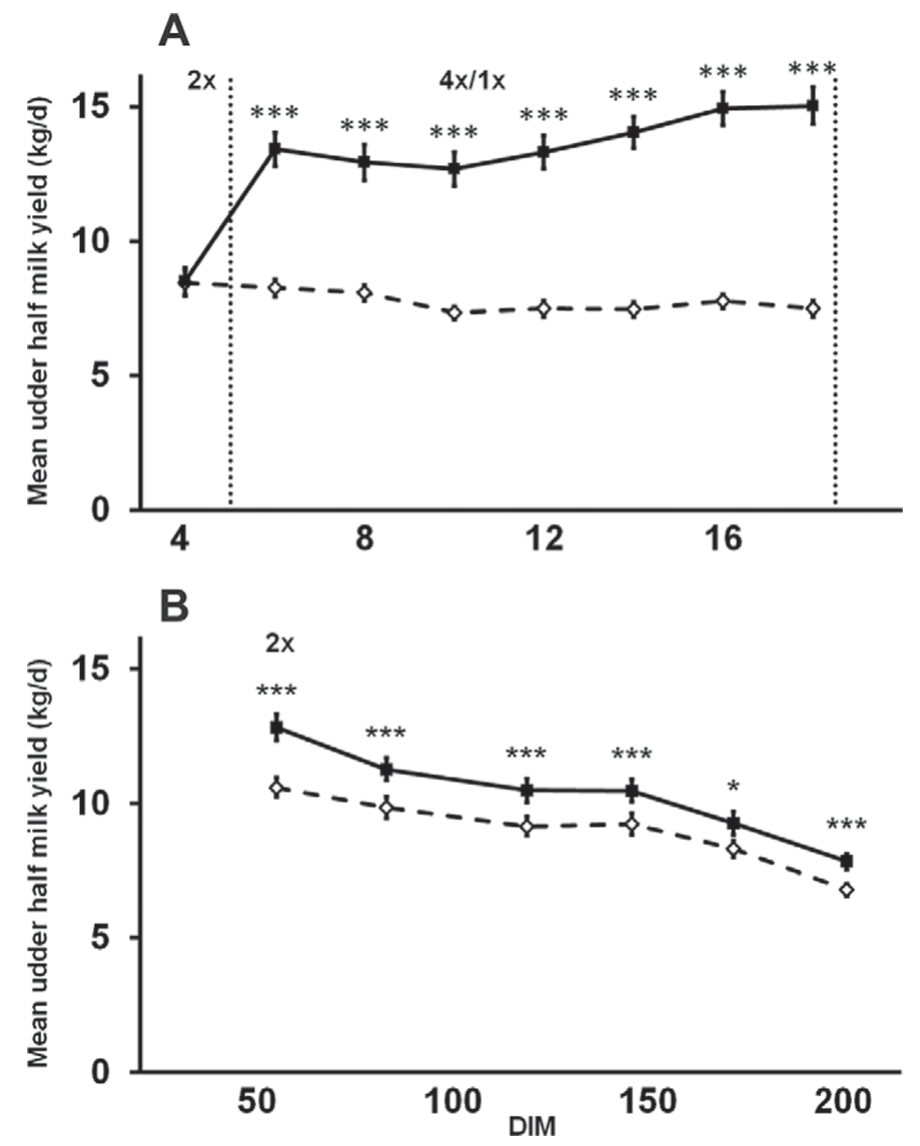

Figure 1. Mean milk yield of udder halves for cows unilaterally milked for $14 \mathrm{~d}$ in early lactation. (A) Cows were milked twice daily $(2 \times ; 3-4$ DIM $)$ and then udder halves were milked either 4 times a day $(4 \times$, solid line) or once a day $(1 \times$, dashed line; $5-19$ DIM). (B) Following the treatment period, cows were returned to $2 \times$ milking for the remainder of lactation (55-200 DIM). Data are expressed as means $\pm \mathrm{SEM} ;{ }^{*} P<0.05,{ }^{* * *} P<0.001$ are for comparisons between $4 \times$ and $1 \times$ yields at each time point..

$4 \times($ Figure $2 \mathrm{C})$ and $1 \times($ Figure $2 \mathrm{D})$ mammary tissue samples. No significant difference in $B A X$-to- $B C L-X L$ ratio was detected between treatments (Figure $2 \mathrm{~B}$ ).

Abundance of mRNA was higher for $\alpha_{\mathrm{S}^{-}} \mathrm{CN}, \beta-\mathrm{CN}$, $\alpha$-LA, and $\beta$-LG in tissue samples from $4 \times$-milked udder halves compared with $1 \times$ (Figure 3 ). In contrast, mRNA abundance for LF, which is elevated in milk during drying off, was lower in tissue samples from $4 \times$-milked udder halves compared with $1 \times($ Figure 3$)$.

\section{DISCUSSION}

Ultimately, milk production in the mammary gland is determined by the number of secretory MEC and the activity of those cells. Secretory MEC number is controlled by the balance between proliferation and apoptosis. Both of these latter processes produce effects gradually over the course of lactation, whereas 
secretory activity is regulated more acutely. The udder halves milked $4 \times$ responded rapidly, increasing their MY to $60 \%$ more than both pretreatment and $1 \times$ udder halves by d 2 of treatment. Due to the swiftness of response, this acute increase in MY can only be attributed to increased MEC secretory activity in response to the change in MF. This higher secretory activity was maintained for the treatment period and was associated with an increase in expression of the genes encoding the major milk proteins in the $4 \times$-milked mammary tissue samples compared with the $1 \times$ on $\mathrm{d} 14$.

Stelwagen and Knight (1997) reported a small transient compensatory increase of the MY from $2 \times$-milked udder halves when the opposing halves were milked $1 \times$.
A similar effect may have contributed to the increase in MY of the $4 \times$ udder halves reported in our study. However, its contribution could only be minor, as the increase of $4 \times$-milked udder halves was substantially greater than the decrease detected in $1 \times$-milked halves. This effect was attributed to nutrient availability, and would not be expected to persist beyond the UMF treatment period.

Once both udder halves were returned to $2 \times$, the $4 \times$-milked udder halves continued to produce more milk than $1 \times$ udder halves. This carryover effect was detected at all of the time points measured until the end of the trial (i.e., 200 DIM). This observation can be attributed to changes in secretory cell number in
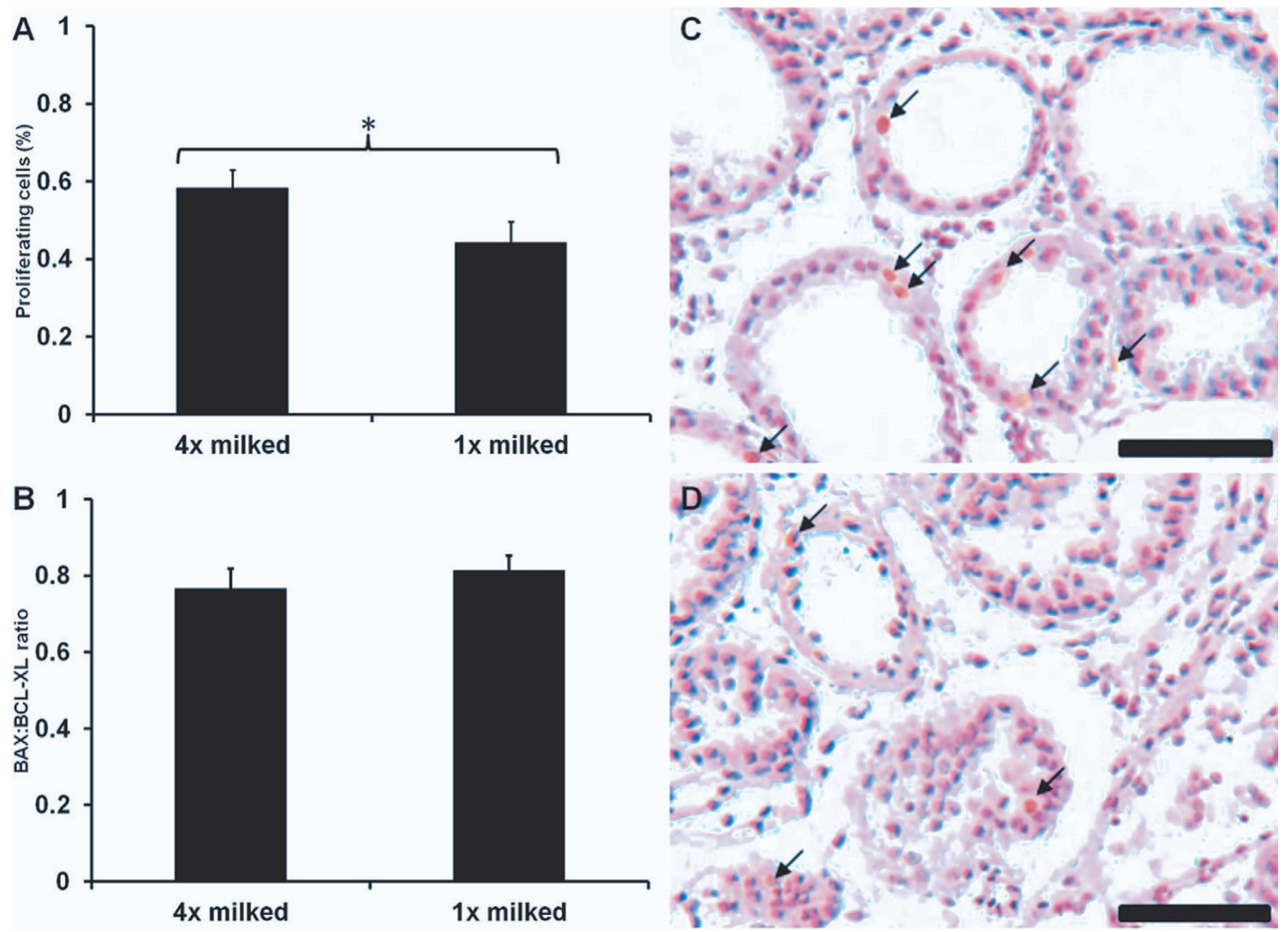

Figure 2. Changes in proliferation and apoptosis in mammary tissue of dairy cows unilaterally milked either 4 times a day $(4 \times)$ or once a day $(1 \times)$ for $14 \mathrm{~d}$ in early lactation (19 DIM). (A) Percentage of cells stained positively for the proliferation marker Ki-67 on sections of formaldehyde-fixed, paraffin-embedded mammary tissue biopsied from unilaterally milked udder halves. (B) Ratio of pro-apoptotic Bcl-2-associated X $(B A X)$ and anti-apoptotic B-cell lymphoma-extra-large $(B C L-X L)$ mRNA measured by real time reverse transcription-PCR in mammary tissue biopsied from unilaterally milked udder halves. Bars indicate SEM; $* P<0.05$. (C and D) Representative Ki- 67 staining in formaldehyde-fixed, paraffin-embedded mammary tissue biopsied from unilaterally milked udder halves either milked $4 \times(\mathrm{C})$ or $1 \times(\mathrm{D})$. Arrows indicate positively stained cells, alveolar lumen ( $\mathrm{Lu})$, bar represents $50 \mu \mathrm{m}$. 
response to MF. Proliferation and apoptosis were therefore measured on d 14 of the treatment. Proliferation was significantly higher in the $4 \times$-milked mammary tissue samples compared with $1 \times$, whereas no difference in apoptosis-related gene expression was noted. This indicates that the carryover effect on MY is due to increased proliferation, resulting in greater numbers of secretory cells in the $4 \times$ compared with $1 \times$ treatment. Some previous studies investigating the effects of increased MF in early lactation did not detect a significant change in proliferation or apoptosis (Hale et al., 2003, Nørgaard et al., 2005, Wall and McFadden, 2010). Grala et al. (2011) did detect an increase in apoptotic markers in $1 \times$-milked mammary tissue samples compared with $2 \times$, but effects on proliferation were not reported; therefore, the overall effect on cell turnover was not ascertained. Whereas, when $3 \times$ and $1 \times$ MF were compared in midlactation, an increase in both proliferation and apoptosis was detected in the $1 \times$-milked udder halves following 4 wk of treatment (Bernier-Dodier et al., 2010). The discrepancy between reports remains unclear, but it may be due to the differences in the parameters of the experiments (i.e., stage of lactation, duration of treatment, and time of sample collection in relation to previous milking). Furthermore, the results reported in the present study are the first description of a carryover effect on MY in response to MF in pasture-fed dairy cows. Unlike previous experiments in pasture-based systems (McNamara et al., 2008, Phyn et al., 2011), the present study used a unilateral milking model, which by decreasing the confounding effects of nutrition and genetics increases the likelihood of detecting small changes in MY and cell turnover in response to MF. In addition, the difference between the treatments $(4 \times$ vs. $1 \times)$ was more extreme than in previous studies.

In the current study it has not been ascertained how changes in MF modulate the secretory activity and number of MEC, but previous studies have investigated possible signaling pathways that could be involved. Expression of prolactin receptors has been demonstrated to be increased with higher MF in midlactation in bovine mammary glands (Bernier-Dodier et al., 2010). Whereas McKinnon et al. (1988) detected an increase in the prolactin-binding capacity of goat mammary glands when subjected to increased MF. This would facilitate an increased sensitivity to prolactin, and thereby increase MEC activity and cell number (reviewed in Knight, 2001). Changes in the expression of IGF-1 and IGF binding proteins within the mammary gland may increase the bioavailability of IGF1, potentially increasing MEC activity and stimulating proliferation (reviewed in Cohick, 1998). Bernier-Dodier et al. (2010) detected an increase in IGF1 mRNA in response to in- creased MF in midlactation. Whereas in early lactation Wall and McFadden (2010) identified a decrease in IGF binding protein $3 \mathrm{mRNA}$ in response to milk removal associated with increased MF. Evidence suggests that, in $1 \times$-milked mammary glands at $18 \mathrm{~h}$ postmilking, the mammary gland reaches a level of milk capacity that begins to detrimentally affect the rate of milk synthesis (Stelwagen, 2001). A loss of mammary cell tight junction integrity occurs at this time, which interrupts the barrier between the alveolar lumen and the extracellular space, allowing the passage of milk constituents out of and blood constituents into the lumen, which could be the signal for secretory activity to cease (Stelwagen, 2001). Previous studies in sheep and beef cattle mammary glands have shown that LF is expressed in alveoli that were not expressing $\alpha$-LA and may be indicative of when the mammary alveoli enter a nonsecretory state (Molenaar et al., 1992). Therefore, the significant increase in LF expression in $1 \times$-milked mammary tissue samples may indicate a switch of secretory cells into a more nonsecretory quiescent state compared with $4 \times$, as postulated by Vetharaniam et al. (2003).

A net increase in fat, protein, and lactose yield was measured in the post-treatment period in the $4 \times \mathrm{ud}-$ der halves compared with $1 \times$, which was consistent with previous studies (Bar-Peled et al., 1995, Wall and McFadden, 2007). In comparison, Phyn et al. (2011), when measuring the effects of a 3 -wk treatment of $1 \times$ compared with $2 \times$, did not detect any difference in MY; however, a carryover decrease in milk solids was detected following $1 \times$ treatment.

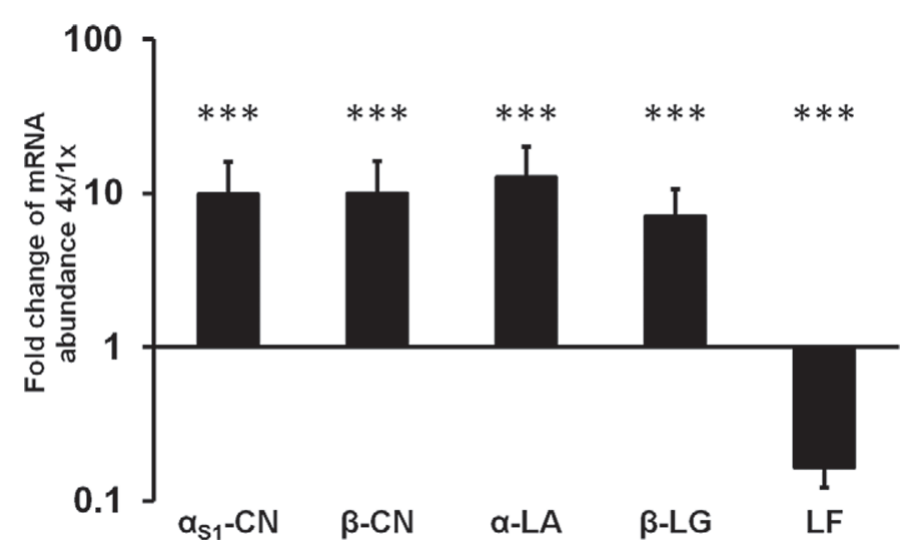

Figure 3. Difference in mRNA abundance for milk protein genes $\alpha_{\mathrm{S} 1} \mathrm{CN}, \beta-\mathrm{CN}, \alpha-\mathrm{LA}, \beta-\mathrm{LG}$, and lactoferrin (LF) expressed in mammary tissue from udder halves of dairy cows that had been subjected to unilateral milking 4 times a day $(4 \times)$ or once a day $(1 \times)$. Abundance of mRNA was normalized to the geometric mean of mRNA abundance of 2 housekeeping genes (ubiquitin B and $\beta 2$-microglobulin) and expressed as a fold change in $4 \times$ compared with $1 \times$. Data are expressed as mean fold change with bars indicating standard error of the difference; $* * * P<0.001$. 
In conclusion, during early lactation in pasture-fed cows, a 14-d UMF treatment of $4 \times$ versus $1 \times$ had an effect on MY, mammary cell proliferation, and major milk protein gene expression. Following the UMF treatment, a long-term carryover effect on MY was also observed. The results demonstrate that, even under a nutrient-restricted diet, as is the case in pasture-fed systems, bovine mammary glands can still positively respond to MF stimulus. The increase of MEC proliferation, with $4 \times$ compared with $1 \times \mathrm{MF}$, may explain how this carryover effect on MY is established.

\section{ACKNOWLEDGMENTS}

The authors acknowledge the lactation biology team members and farm staff at the Tokanui Research Farm (AgResearch; South Waikato, New Zealand) for assistance with the animal trial and sample collections and the statistical advice of Harold Henderson (AgResearch). This research was funded by a Ministry of Business, Innovation \& Employment (Wellington, New Zealand) research grant C10X0702.

\section{REFERENCES}

Amos, H. E., T. Kiser, and M. Loewenstein. 1985. Influence of milking frequency on productive and reproductive efficiencies of dairy cows. J. Dairy Sci. 68:732-739.

Bar-Peled, U., E. Maltz, I. Bruckental, Y. Folman, Y. Kali, H. Gacitua, A. R. Lehrer, C. H. Knight, B. Robinzon, and H. Voet. 1995. Relationship between frequent milking or suckling in early lactation and milk production of high producing dairy cows. J. Dairy Sci. $78: 2726-2736$.

Bernier-Dodier, P., L. Delbecchi, G. F. Wagner, B. G. Talbot, and P. Lacasse. 2010. Effect of milking frequency on lactation persistency and mammary gland remodeling in mid-lactation cows. J. Dairy Sci. 93:555-564.

Capuco, A. V., D. L. Wood, R. Baldwin, K. McLeod, and M. J. Paape. 2001. Mammary cell number, proliferation, and apoptosis during a bovine lactation: relation to milk production and effect of bST1. J. Dairy Sci. 84:2177-2187.

Carruthers, V. R., S. R. Davis, A. M. Bryant, H. V. Henderson, C. A. Morris, and P. J. A. Copeman. 1993. Response of Jersey and Friesian cows to once a day milking and prediction of response based on udder characteristics and milk composition. J. Dairy Res. 60:1-11.

Cohick, W. S. 1998. Role of the insulin-like growth factors and their binding proteins in lactation. J. Dairy Sci. 81:1769-1777.

Erdman, R. A., and M. Varner. 1995. Fixed yield responses to increased milking frequency. J. Dairy Sci. 78:1199-1203.

Farr, V. C., K. Stelwagen, L. R. Cate, A. J. Molenaar, T. B. McFadden, and S. R. Davis. 1996. An Improved method for the routine biopsy of bovine mammary tissue. J. Dairy Sci. 79:543-549.

Grala, T. M., C. V. C. Phyn, J. K. Kay, A. G. Rius, M. D. Littlejohn, R. G. Snell, and J. R. Roche. 2011. Temporary alterations to milking frequency, immediately post-calving, modified the expression of genes regulating milk synthesis and apoptosis in the bovine mammary gland. Proc. N.Z. Soc. Anim. Prod. 71:3-8.

Hale, S. A., A. V. Capuco, and R. A. Erdman. 2003. Milk yield and mammary growth effects due to increased milking frequency during early lactation. J. Dairy Sci. 86:2061-2071.
Hillerton, J. E., C. H. Knight, A. Turvey, S. D. Wheatley, and C. J. Wilde. 1990. Milk yield and mammary function in dairy cows milked four times daily. J. Dairy Res. 57:285-294.

Knight, C. H. 2001. Overview of prolactin's role in farm animal lactation. Livest. Prod. Sci. 70:87-93.

McKinnon, J., C. H. Knight, D. J. Flint, and C. J. Wilde. 1988. Effect of milking frequency and efficiency on goat mammary prolactin receptor number. J. Endocrinol. 119:167.

McMahon, C. D., V. C. Farr, K. Singh, T. T. Wheeler, and S. R. Davis. 2004. Decreased expression of $\beta 1$-integrin and focal adhesion kinase in epithelial cells may initiate involution of mammary glands. J. Cell. Physiol. 200:318-325.

McNamara, S., J. J. Murphy, F. P. O'Mara, M. Rath, and J. F. Mee. 2008. Effect of milking frequency in early lactation on energy metabolism, milk production and reproductive performance of dairy cows. Livest. Sci. 117:70-78.

Molenaar, A. J., S. R. Davis, and R. J. Wilkins. 1992. Expression of alpha-lactalbumin, alpha-S1-casein, and lactoferrin genes is heterogeneous in sheep and cattle mammary tissue. J. Histochem. Cytochem. 40:611-618.

Nørgaard, J., A. Sørensen, M. T. Sørensen, J. B. Andersen, and K. Sejrsen. 2005. Mammary cell turnover and enzyme activity in dairy cows: Effects of milking frequency and diet energy density. J. Dairy Sci. 88:975-982.

Phillips, D., M. Woolford, and P. Copeman. 1980. The implications of milking management strategies involving variations of milking frequency in the immediate post-partum period. Proc. N.Z. Soc. Anim. Prod. 40:166-174.

Phyn, C. V. C., J. K. Kay, A. G. Rius, S. R. Morgan, C. S. Roach, T. M. Grala, and J. R. Roche. 2011. Effect of temporary alterations to milking frequency during the early post-partum period on milk production and body condition score in grazing dairy cows. Proc. N.Z. Soc. Anim. Prod. 71:45-49.

Rémond, B., J. B. Coulon, M. Nicloux, and D. Levieux. 1999. Effect of temporary once-daily milking in early lactation on milk production and nutritional status of dairy cows. Ann. Zootech. (Paris) 48:341-352.

Rozen, S., and H. Skaletsky. 2000. Primer3 on the WWW for general users and for biologist programmers. Methods Mol. Biol. 132:365-386.

Singh, K., S. R. Davis, J. M. Dobson, A. J. Molenaar, T. T. Wheeler, C. G. Prosser, V. C. Farr, K. Oden, K. M. Swanson, C. V. C. Phyn, D. L. Hyndman, T. Wilson, H. V. Henderson, and K. Stelwagen. 2008. cDNA microarray analysis reveals that antioxidant and immune genes are upregulated during involution of the bovine mammary gland. J. Dairy Sci. 91:2236-2246.

Singh, K., J. Dobson, C. V. C. Phyn, S. R. Davis, V. C. Farr, A. J. Molenaar, and K. Stelwagen. 2005. Milk accumulation decreases expression of genes involved in cell-extracellular matrix communication and is associated with induction of apoptosis in the bovine mammary gland. Livest. Prod. Sci. 98:67-78.

Stelwagen, K. 2001. Effect of milking frequency on mammary functioning and shape of the lactation curve. J. Dairy Sci. 84:E204-E211.

Stelwagen, K., and C. H. Knight. 1997. Effect of unilateral once or twice daily milking of cows on milk yield and udder characteristics in early and late lactation. J. Dairy Res. 64:487-494.

Vetharaniam, I., S. R. Davis, T. K. Soboleva, P. R. Shorten, and G. C. Wake. 2003. Modeling the interaction of milking frequency and nutrition on mammary gland growth and lactation. J. Dairy Sci. 86:1987-1996.

Wall, E. H., and T. B. McFadden. 2007. The milk yield response to frequent milking in early lactation of dairy cows is locally regulated. J. Dairy Sci. 90:716-720.

Wall, E. H., and T. B. McFadden. 2010. The effects of milk removal or four-times-daily milking on mammary expression of genes involved in the insulin-like growth factor-I axis. J. Dairy Sci. 93:4062-4070. 